\title{
STRATEGI PENINGKATAN PENDAPATAN ASLI DAERAH DI KABUPATEN KEPULAUAN ANAMBAS
}

\author{
Strategy to Increase Local Revenue in Anambas Island Regency
}

\author{
Mukhtar Hakim. R' ${ }^{1}$ Ma'mun Sarma², Harianto ${ }^{3}$ \\ ${ }^{1}$ Staf Dinas Penanaman Modal, PTSP, Tenaga Kerja dan Transmigrasi, Kabupaten Kepulauan Anambas, Provinsi Kepulauan \\ Riau. E-mail : akunhakim87@gmail.com \\ ${ }^{2}$ Staff Pengajar Departemen Manajemen, Fakultas Ekonomi dan Manajemen, IPB. E-mail : mamun_sarma@yahoo.com \\ ${ }^{3}$ Staff Pengajar Departemen Agribisnis, Fakultas Ekonomi dan Manajemen, IPB. E-mail : harianto.IPB@gmail.com
}

\begin{abstract}
Realization of Local Revenue (PAD) Anambas Islands Regency fluctuates through years, even tends to decline. The main problems faced in achieving the PAD target are due to (1) exploration of potential sources of regional income which is not optimal; (2) limitation of good quality of government'servant resources; (3) working culture of the servant in carrying out public services which is not optimal yet; (4) inadequate supporting facilities and infrastructures; (5) development of information systems in local financial management which is not optimal. The general objective of this research was to formulate strategies to increase PAD in Anambas Islands Regency. The study was conducted in Anambas Islands District on divisons and agencies which directly related to PAD. Primary data were obtained from direct interview, while secondary data were obtained from reports and documents from various related agencies. Data were analyzed by analysis of effectiveness ratio, efficiency ratio and regional independence ratio. The results of this study are (1) the effectiveness of regional income of Anambas Islands Regency during 2011-2015 fluctuated and the efficiency of $P A D$ in Anambas Islands Regency tended to increase, (2) The ratio of regional independence was still low, (3) The main strategy implemented in the Anambas Islands Regency in order to increase PAD was an improvement in the management of regional income by optimizing the potential of PAD.
\end{abstract}

Keyword : Local Revenue (PAD), Effectiveness, Efficiency, Independence, Strategy to Increase

\begin{abstract}
ABSTRAK
Realisasi PAD Kabupaten Kepulauan Anambas dari tahun ke tahun mengalami fluktuasi, bahkan cendrung mengalami penurunan. Permasalahan utama yang dihadapi dalam mencapai target PAD disebabkan oleh (1) Belum optimalnya penggalian potensi sumber-sumber penerimaan daerah; (2) Masih terbatasnya Sumberdaya Aparatur Pemerintah yang berkualitas; (3) Belum optimalnya budaya kerja aparatur dalam melaksanakan pelayanan publik; (4) Sarana dan Prasarana penunjang yang kurang memadai; (5) Belum optimalnya pengembangan sistem informasi dalam pengelolaaan keuangan daerah. Tujuan umum dari penelitian ini adalah untuk merumuskan strategi peningkatan PAD di Kabupaten Kepulauan Anambas. Tempat kajian dilakukan di Kabupaten Kepulauan Anambas pada Dinas dan instansi yang berkaitan langsung dengan PAD. Data primer diperoleh dari wawancara langsung, sedangkan data sekunder diperoleh dari laporan dan dokumen yang didapat dari berbagai instansi terkait. Data dianalisis dengan analisis rasio efekivitas, rasio efisiensi dan rasio kemandirian daerah. Hasil yang didapat dari kajian ini (1) Efektivitas PAD Kabupaten Kepulauan Anambas selama tahun 2011-2015 berfluktuasi dan efisiensi PAD Kabupaten Kepulauan Anambas cenderung membaik, (2) Rasio kemandirian daerah masih rendah, (3) Strategi prioritas utama yang di terapkan di Kabupaten Kepulauan Anambas untuk meningkatkan PAD adalah peningkatan dalam pengelolaan pendapatan daerah dengan mengoptimalkan potensi PAD
\end{abstract}

Kata kunci : Pendapatan Asli Daerah (PAD), Efektivitas, Efisiensi, Kemandirian, Strategi Peningkatan

\section{PENDAHULUAN}

Pelaksanaan otonomi daerah yang dimulai pada tanggal 1 Januari Tahun 2001 menimbulkan reaksi yang berbeda-beda bagi daerah. Pemerintah Daerah yang memiliki kekayaan alam menyambut baik otonomi daerah dengan penuh harapan, sebaliknya daerah yang miskin sumberdaya alamnya menanggapinya 
secara hati-hati. Kekhawatiran beberapa daerah tersebut bisa dipahami karena pelaksanaan otonomi daerah dan desentralisasi membawa konsekuensi Pemerintah Daerah untuk lebih mandiri baik dari sistem pembiayaan maupun menentukan arah pembangunan daerah sesuai dengan prioritas dan kepentingan masyarakat di daerah.

Pelaksanaan otonomi daerah didasarkan pada Undang-Undang No. 22 Tahun 1999 tentang Pemerintahan Daerah yang telah direvisi dengan UndangUndang No. 32 Tahun 2004 dan UndangUndang No. 23 Tahun 2014. Sejalan dengan itu, Undang-Undang No. 25 Tahun 1999 tentang Perimbangan Keuangan antara Pemerintah Pusat dan Daerah juga mengalami perubahan dengan diberlakukannya Undang-Undang No. 33 Tahun 2004 tentang Perimbangan Keuangan antara Pemerintah Pusat dan Pemerintah Daerah, maka pelaksanaan otonomi daerah diharapkan dapat mendorong peningkatan partisipasi dan kreativitas masyarakat serta mendorong pemerataan pembangunan daerah dengan memanfaatkan sumberdaya dan potensi yang tersedia.

Penyelenggaraan otonomi daerah khususnya di Kabupaten Kepulauan
Anambas berdasarkan Undang-Undang Nomor 33 Tahun 2008 tanggal 21 Juli 2008 tentang Pembentukan Kabupaten Kepulauan Anambas. Sejak itu pula pelaksanaan pemerintahan dan pembangunan secara otonomi telah dilaksanakan, secara otomatis diikuti dengan sejumlah pembiayaan. Kabupaten Kepulauan Anambas dalam melaksanakan kegiatan pemerintahan dan pemerataan pembangunan tidak terlepas dari sumber dan pembiayaan, yang dalam hal ini adalah Anggaran Pendapatan dan Belanja Daerah (APBD). Secara konseptual APBD merupakan alat untuk menjalankan otonomi daerah yang nyata dan bertanggung jawab berupa rencana operasional pemerintah daerah. APBD menggambarkan pengeluaran untuk kegiatan pemerintahan dan proyek daerah. Proporsi APBD Kabupaten Kepulauan Anambas saat ini sebagian besar masih bersumber dari pemerintah pusat dalam bentuk Dana Alokasi Umum (DAU), Dana Alokasi Khusus (DAK) dan Dana Bagi Hasil (DBH). Sedangkan pendapatan daerah yang bersumber dari PAD masih sangat kecil. Gambar 1 memerlihatkan perbandingan antara PAD dengan APBD Kabupaten Kepulauan Anambas dari Tahun 2009 sampai dengan 2015.

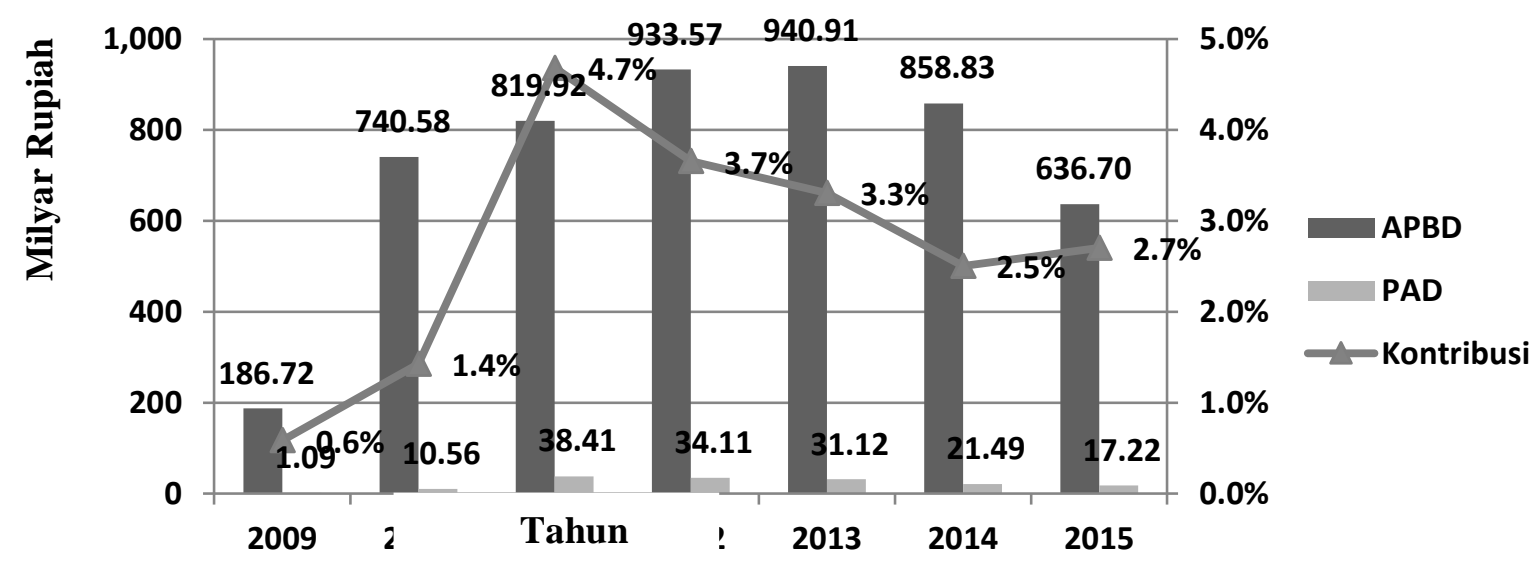

Sumber: Badan Keuangan Daerah Kab. Kep. Anambas Tahun 2016, data diolah

Gambar 1 Perbandingan APBD dan PAD Kabupaten Kepulauan Anambas Tahun 2009-2015 (dalam milyar Rp)

Berdasarkan grafik pada Gambar 1, penerimaan dari PAD setiap tahunnya mengalami peningkatan pada Tahun 2009-
2011 dan mengalami penurunan pada Tahun 2011-2015. Begitu juga dengan APBD yang mengalami fluktuasi dari 
tahun ke tahun. Dilihat dari data di atas, kontribusi PAD terhadap APBD relatif sangat kecil dan dapat dikategorikan rendah atau dibawah 50\%. Tahun 2015 kontribusi PAD Kabupaten Kepulauan Anambas hanya sebesar 2,7\% dari APBD Kabupaten Kepulauan Anambas, ini berarti Kabupaten Kepulauan Anambas masih sangat tergantung terhadap dana bantuan dari pemerintah pusat. Kondisi tersebut memerlukan strategi yang tepat dalam meningkatkan PAD. Diberlakukannya UU Otonomi Daerah diharapkan daerah lebih mandiri dan proaktif dalam meningkatkan PAD sehingga tidak tergantung pada pemerintah pusat. Baihaqi (2011) dalam penelitiannya menyebutkan penyebab turunnya kontribusi PAD terhadap Pendapatan Daerah adalah karena pemerintah kurang fokus dalam meningkatkan PAD secara keseluruhan. Sedangkan menurut Halim (2016), salah satu penyebab utama rendahnya PAD sehingga tingginya ketergantungan daerah terhadap pusat adalah perhitungan potensi tidak dilakukan.

Permasalahan yang terjadi di Kabupaten Kepulauan Anambas terkait tidak menentunya Penerimanan PAD dan rendahnya kontribusi PAD terhadap penerimaan daerah adalah (i) belum optimalnya penggalian potensi sumbersumber penerimaan daerah; (ii) masih terbatasnya Sumberdaya Aparatur Pemerintah yang berkualitas; (iii) belum optimalnya budaya kerja aparatur dalam melaksanakan pelayanan publik; (iv) sarana dan prasarana penunjang yang kurang memadai; (v) belum optimalnya pengembangan sistem informasi dalam pengelolaaan keuangan daerah.

Dengan mengetahui permasalahan tersebut akan memudahkan pengambil keputusan untuk menentukan strategi apa yang diambil sehingga PAD bisa meningkat dari tahun ketahun, maka tujuan dari penelitian ini adalah 1) Menganalisis efektifitas dan efisiensi PAD di Kabupaten Kepulauan Anambas; 2) menganalisis rasio kemandirian daerah Kabupaten Kepulauan Anambas; 3) merumuskan strategi yang

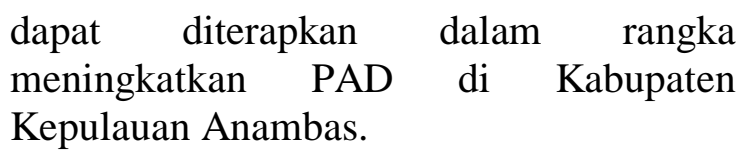

\section{METODE PENELITIAN}

Kajian ini dilakukan di Kabupaten Kepulauan Anambas, Provinsi Kepulauan Riau, dengan pertimbangan bahwa wilayah ini memiliki potensi untuk peningkatan Pendapatan Asli Daerah. Responden dalam penelitian adalah responden yang berhubungan dengan kebijakan pengelolaan $\mathrm{PAD}$ dan beberapa dinas lain sebagai dinas penghasil yang turut melakukan pungutan PAD di Kabupaten Kepulauan Anambas. Adapun Responden dari OPD penentu prioritas kebijakan terdiri atas: 1) Badan Penelitian, Pengembangan dan Perencanaan Daerah; 2) DPRD; 3) Badan Keuangan Daerah. Sedangkan Dinas Penghasil PAD terdiri atas :1) Dinas Perikanan, Pertanian dan Pangan; 2) Dinas Kesehatan, Pengendalian Penduduk dan Keluarga Berencana; 3) Dinas Perhubungan dan Lingkungan Hidup; 4) Dinas Penanaman Modal, PTSP, Transmigrasi dan Tenaga Kerja. Masingmasing responden dipillih 1 orang per OPD, sehingga jumlah respondennya adalah 7 orang.

Data yang dikumpulkan dalam rangka mendukung kajian ini yaitu data primer dan data sekunder. Data primer diperoleh dari wawancara langsung terhadap sumber informasi yang telah ditentukan. Data primer juga didapat dari angket/kuesioner pada pihak yang terkait. Sedangkan data sekunder diperoleh dari laporan dan dokumen yang dikeluarkan oleh Badan Keuangan Daerah seperti data pendapatan, biaya pemerolehan PAD, dll. Data sekunder juga didapat dari berbagai instansi terkait seperti dari Badan Penelitian, Pengembangan dan Perencanaan Daerah (Balitbangpeda), Badan Pusat Statistik (BPS), peraturan perundang-undangan, literatur, jurnal, dan informasi lainnya yang berhubungan dengan topik kajian. 
Data primer dan sekunder yang didapat kemudian diolah dan dianalisis untuk mendapatkan rekomendasi sebagai strategi kebijakan pemerintah daerah dalam rangka peningkatan PAD di Kabupaten Kepulauan Anambas. Untuk mendapatkan strategi tersebut terdapat tahapan yang harus dilakukan. Tahap Pertama adalah melakukan analisis efektifitas dan efisiensi PAD beserta komponennya.

Untuk analisis efektivitas, efisiensi dan kemandirian dilakukan dengan memakai rasio-rasio keuangan antara lain (Mahmudi, 2010):

\section{a. Rasio Efektifitas}

Tingkat Efektifitas digunakan untuk mengukur upaya pemungutan PAD yang telah dilakukan oleh Pemerintah Daerah. Rumus efektivitas yang digunakan adalah:

$$
\text { Efektifitas }=\frac{\text { Realisasi Penerimaan } P A D}{\text { Target Penerimaan } P A D} \times 100 \%
$$

\section{b. Rasio Efisiensi}

Tingkat efisiensi digunakan untuk mengukur seberapa besar biaya yang dibutuhkan untuk mengumpulkan PAD. Rumus efisiensi yang digunakan adalah:

$$
\text { Efisiensi }=\frac{\text { Biaya Pemerolehan } P A D}{\text { Realisasi Penerimaan } P A D} \times 100 \%
$$

\section{c. Rasio Kemandirian}

Rasio kemandirian menggambarkan derajat ketergantungan Pemerintah Daerah terhadap sumber pembiayaan dari pemerintah pusat. Rumus rasio kemandirian yang digunakan adalah :

Rasio Kemandirian $=$

$\frac{\text { Pendapatan Asli Daerah }}{\text { Bantuan Pemerintah Pusat/Propinsi dan Pinjaman }}$ X 100\%

Tahap kedua adalah penyusunan strategi yang diperlukan untuk meningkatkan PAD di Kabupaten Kepulauan Anambas. Adapun tahapan ini dibagi beberapa tahapan. Pertama, 18 Tahapan Input Strategi, dimana dalam tahap ini mengunakan Analisis Faktor Internal dan Eksternal yang diringkas agar dapat dilakukan analisis dengan menggunakan Tabel/Matriks Evaluasi Internal-Ekternal (Matriks IFE/EFE), dengan memberikan bobot serta peringkat untuk masing-masing faktor yang mencerminkan tingkat kepentingan suatu faktor dibandingkan faktor lainnya (David 2015). Kedua, Setelah diperoleh hasil pembobotan IFE-EFE selanjutnya akan dilakukan interaksi kombinasi dari strategi yang meliputi kombinasi internal eksternal menggunakan Matriks SWOT. Ketiga, Tahapan Keputusan Strategi, dimana dalam tahap ini memakai Analisis QSPM yang merupakan tahap keputusan strategi yang akan dilakukan berdasarkan alternatif solusi yang didapat dari langkah pertama sampai ketiga sehingga akan menentukan daya tarik relatif dari berbagai strategi berdasarkan sejauh mana faktor-faktor sukses kritis internal ekternal dimanfaatkan atau diperbaiki sehingga akan menghasilkan prioritas strategi yang akan dilakukan.

\section{HASIL DAN PEMBAHASAN}

\section{Analisis Rasio Efektivitas PAD}

Rasio efektivitas menunjukkan kemampuan pemerintah daerah dalam merealisasikan pendapatan asli daerah (PAD) yang direncanakan dibandingkan dengan target yang ditetapkan berdasarkan potensi daerah. Kemampuan daerah dikategorikan efektif apabila rasio yang dicapai mencapai 1 (satu) atau 100 persen. Efektivitas PAD di Kabupaten Kepulauan Anambas selama periode kajian 2011-2015 dapat dikatakan berfluktuasi. Pada Tahun 2011 efektivitas PAD sebesar 153,30 persen, kemudian pada Tahun 2012 mengalami penurunan menjadi 81,72. Selanjutnya pada Tahun 2013 efektivitas PAD mengalami peningkatan menjadi 100,30. Pada Tahun 2014 kembali mengalami penurunan menjadi 65,43 persen dan pada Tahun 2015 mengalami sedikit peningkatan menjadi 80,78 persen. Untuk lebih jelasnya dapat dilihat pada Tabel 1 berikut. 
Tabel 1. Efektivitas PAD di Kabupaten Kepulauan Anambas Tahun 2011-2015

\begin{tabular}{|c|c|c|c|c|c|c|}
\hline No & Uraian & 2011 & 2012 & 2013 & 2014 & 2015 \\
\hline 1 & Pajak Daerah & 102,51 & 69,54 & 114,39 & 127,23 & 52,62 \\
\hline 2 & ، Retribusi Daerah & 119,71 & 147,13 & 90,65 & 88,17 & 264,56 \\
\hline 3 & $\begin{array}{l}\text { Bagian Laba } \\
\text { Usaha Daerah }\end{array}$ & Nihil & Nihil & 100,00 & 795,72 & 100,00 \\
\hline 4 & $\begin{array}{c}\text { Lain-lain } \\
\text { Pendapatan }\end{array}$ & 159,43 & 84,79 & 95,95 & 35,76 & 99,13 \\
\hline 5 & $\begin{array}{c}\text { Pendapatan Asli } \\
\text { Daerah }\end{array}$ & 153,30 & 81,72 & 100,30 & 65,43 & 80,78 \\
\hline
\end{tabular}

Sumber: Badan Keuangan Daerah Kab. Kep. Anambas Tahun 2017, Data diolah

Komponen PAD juga berfluktuasi. Pajak daerah pada pada Tahun 2013 sebesar 114,39 persen, kemudian pada tahun 2014 mengalami peningkatan sebesar 127,23. Pada tahun 2015 mengalami penurunan menjadi 52,62 persen. Penurunan tersebut disebabkan karena masih kurangnya kesadaran masyarakat untuk mendaftarkan sebagai wajib pajak dan masih terdapatnya wajib pajak yang tidak membayar pajak tepat waktu. Penurunan ini juga disebabkan akibat dari perekonomian yang menurun sehingga daya beli masyarakat berkurang. Retribusi daerah pada Tahun 2013 sebesar 90,65 persen, kemudian mengalami penurunan menjadi 88,17 persen dan pada Tahun 2015 kembali mengalami peningkatan menjadi 264,56 persen. Kenaikan ini disebabkan karena kesadaran masyarakat meningkat untuk membayar retribusi.

Komponen bagian laba usaha daerah pada Tahun 2013 sebesar 100,00 persen, pada Tahun 2014 mengalami peningkatan signifikan sebesar 795,72 persen. Pendapatan Hasil Pengelolaan Kekayaan Daerah yang Dipisahkan, pendapatannya diterima dan dikelola melalui Sekretariat Daerah Kabupaten Kepulauan Anambas yang berupa PAD dari pembagian laba atas penyertaan modal Pemerintah Daerah Kabupaten Kepulauan Anambas pada Bank Riau Kepri, kemudian pada Tahun 2015 mengalami penurunan menjadi 100,00 persen. Lain-lain pendapatan pada Tahun 2013 sebesar 95,95 persen kemudian mengalami penurunan menjadi 35,76 persen dan pada Tahun 2015 kembali mengalami peningkatan menjadi 99,13 persen. Penurunan Lain-lain Pendapatan pada Tahun 2014 di bandingkan pada Tahun 2013 disebabkan karena adanya penurunan pendapatan bunga deposito dan tidak tercapainya target penerimaan pendapatan deposito.

\section{Analisis Rasio Efisiensi PAD}

Rasio efisiensi adalah rasio yang menggambarkan perbandingan antara besarnya biaya yang dikeluarkan untuk memperoleh pendapatan dengan realisasi pendapatan yang diterima. Untuk itu pemerintah daerah perlu menghitung secara cermat berapa besarnya biaya yang dikeluarkan untuk merealisasikan seluruh pendapatan yang diterimanya sehingga dapat diketahui apakah kegiatan yang dilakukan untuk memperoleh PAD tersebut sudah efisien atau tidak. Hal itu perlu dilakukan karena meskipun pemerintah daerah berhasil merealisasikan penerimaan pendapatan sesuai dengan target yang ditetapkan, namun keberhasilan itu kurang memiliki arti apabila ternyata biaya yang dikeluarkan untuk merealisasikan target penerimaan pendapatannya itu lebih besar daripada realisasi pendapatan yang diterimanya. Kemampuan daerah dikategorikan efisien apabila rasio yang dicapai sebesar 10-20 persen dan <10 dikatakan sangat efisien.

Untuk rasio efisiensi PAD di Kabupaten Kepulauan Anambas, 
berdasarkan pada Tabel 2 terlihat tingkat efisiensi pada Tahun 2012 sebesar 10,22 persen yang masih dikategorikan efisien. Akan tetapi, pada tahun-tahun berikutnya tingkat efisiensi semakin membaik. Hal ini dapat dilihat dari rasio efisiensi pada
Tahun 2013 sebesar 9,41 pada Tahun 2014 sebesar 9,48 persen dan pada Tahun 2015 rasio efisiensi menjadi 1,78 persen yang dikategorikan sangat efisien. Untuk lebih jelasnya dapat dilihat pada Tabel 2 berikut ini.

Tabel 2 Efisiensi PAD di Kabupaten Kepulauan Anambas Tahun 2011-2015

\begin{tabular}{cccc}
\hline Tahun & $\begin{array}{c}\text { Biaya Pemerolehan PAD } \\
\text { (juta rupiah) }\end{array}$ & $\begin{array}{c}\text { Realisasi PAD } \\
\text { (juta rupiah) }\end{array}$ & $\begin{array}{c}\text { Efisiensi } \\
\text { (persen) }\end{array}$ \\
\hline 2011 & $3.463,17$ & $38.407,26$ & 9,02 \\
2012 & $3.486,34$ & 34.108 .38 & 10,22 \\
2013 & $2.928,78$ & $31.123,66$ & 9,41 \\
2014 & $2.038,07$ & $21.489,58$ & 9,48 \\
2015 & 307,10 & $17.218,36$ & 1,78 \\
\hline
\end{tabular}

Sumber: Badan Keuangan Daerah Kab. Kep. Anambas Tahun 2017, data diolah

Analisis Rasio Kemandirian (Otonomi Fiskal)

Struktur Penerimaan Pemerintah Kabupaten Kepulauan Anambas terdiri dari pertama Pendapatan Asli Daerah yang terdiri dari pajak, retribusi, hasil pengelolaan kekayaan daerah yang dipisahkan dan lain-lain pendapatan yang sah. Kedua, dana perimbangan yang terdiri dari bagi hasil pajak, dana alokasi umum (DAU), dana alokasi khusus (DAK). Ketiga, yaitu dari lain-lain pendapatan daerah yang sah yang terdiri dari bagi hasil pajak dan bantuan propinsi, dana penyesuaian dan penerimaan lain-lain.
Dari ketiga jenis penerimaan, yang paling dominan adalah penerimaan dari dana perimbangan. Idealnya adalah semakin tinggi PAD suatu daerah, maka ketergantungan terhadap dana perimbangan dari pemerintah pusat semakin rendah. Hal ini terkait dengan kemampuan suatu daerah dalam mengoptimalkan potensi pendapatan di daerahnya. Tren pertumbuhan rasio kemandirian Kabupaten Kepulauan Anambas dapat dilihat pada Tabel 3 berikut.

Tabel 3. Rasio Kemandirian Kabupaten Kepulauan Anambas terhadap Bantuan Pemerintah dan Pinjaman Tahun 2011-2015

\begin{tabular}{cccc}
\hline Tahun & $\begin{array}{c}\text { Realisasi PAD (Milyar } \\
\text { Rupiah) }\end{array}$ & $\begin{array}{c}\text { Bantuan Pemerintah dan } \\
\text { Pinjaman (Milyar } \\
\text { Rupiah) }\end{array}$ & $\begin{array}{c}\text { Rasio } \\
\text { Kemandirian (\%) }\end{array}$ \\
\hline 2011 & 38.41 & 766.59 & 5.01 \\
2012 & 34.11 & 887.76 & 3.84 \\
2013 & 31.12 & 888.33 & 3.50 \\
2014 & 21.49 & 815.08 & 2.64 \\
2015 & 17.22 & 561.71 & 3.07 \\
\hline
\end{tabular}

Sumber: Badan Keuangan Daerah Kab. Kep. Anambas Tahun 2017, data diolah

Dari tabel 3 di atas menunjukkan bahwa Kabupaten Kepulauan Anambas masih mengandalkan dana perimbangan dari pemerintah pusat baik itu dari dana alokasi umum (DAU) maupun dana alokasi khusus (DAK) dan lain-lain pendapatan daerah yang sah untuk membiayai pembangunan daerahnya. Kontribusi pendapatan asli daerah Kabupaten Kepulauan Anambas dalam anggaran pendapatan dan belanja daerah (APBD) relatif sangat kecil. Besarnya jumlah 
APBD sangat dipengaruhi oleh besarnya jumlah dana perimbangan dari pemerintah pusat. Hal ini berarti bahwa pemerintah Kabupaten Kepulauan Anambas belum bisa mengandalkan PAD saja untuk membiayai pembangunan di daerahnya. Keberhasilan otonomi daerah tidak hanya ditentukan besarnya PAD atau kapasitas keuangan yang dimiliki daerah tetapi juga oleh beberapa faktor lain yang mempengaruhinya. Sebagaimana yang dikemukakan oleh Kaho (1997), keberhasilan pelaksanaan otonomi daerah dipengaruhi oleh beberapa faktor, yaitu 1) Faktor manusia; 2) Faktor keuangan; 3) Faktor peralatan; 4) Faktor organisasi dan manajemen.

\section{STRATEGI PENINGKATAN PENDAPATAN ASLI DAERAH DI KABUPATEN KEPULAUAN ANAMBAS}

\section{Tahapan Input Strategi}

Tahap input dalam kerangka kerja perumusan strategi pada penelitian ini terdiri atas matriks IFE dan matriks EFE. Berdasarkan hasil matriks IFE untuk elemen kekuatan diperoleh skor sebesar 2,032 sedangkan skor untuk elemen kelemahan sebesar 0,925. Hal ini menunjukan bahwa seluruh responden memberikan pandangan yang cukup tinggi pada faktor kekuatan dan respon yang relatif kecil untuk faktor kelemahan. Hasil perhitungan IFE menunjukkan bahwa kebijakan pemerintah daerah dalam meningkatkan pendapatan daerah sebagai kekuatan utama bagi Pemerintah Kabupaten Kepulauan Anambas dengan nilai tertimbang paling tinggi sebesar 0,520 yang ditunjukkan dengan nilai rating 3.86. Berdasarkan perhitungan untuk faktor kelemahan, target belum sepenuhnya berdasarkan potensi yang ada menjadi kelemahan bagi Pemerintah Kabupaten Kepulauan Anambas dengan nilai tertimbang sebesar 0,233. Target belum berdasarkan potensi yang ada berhubungan dengan rasio efektivitas PAD tahun 2015 yang dinilai kurang efektif dikarenakan selama ini target dihitung berdasarkan persentase tahun sebelumnya.

Sedangkan hasil dari matriks EFE untuk elemen peluang diperoleh skor sebesar 1,574, sedangkan skor untuk elemen ancaman sebesar 1,291. Hal ini menunjukan bahwa seluruh responden memberikan respon yang cukup tinggi pada faktor peluang dan respon yang relatif kecil untuk faktor ancaman. Hasil perhitungan dan evaluasi faktor-faktor eksternal dengan mempergunakan matriks EFE menunjukkan bahwa faktor masih ada objek pajak/retribusi yang belum tergali merupakan peluang utama dengan skor tertinggi 0.479. Sedangkan faktor ancaman yaitu mutasi dan promosi jabatan terhadap aparatur pengelola PAD merupakan ancaman utama dengan nilai tertimbang sebesar 0.326. Terjadinya mutasi dan promosi jabatan terhadap pengelola PAD akan membuat pegawai baru yang menggantikan posisi tersebut akan memulai dari awal dalam hal pengelolaan PAD. Hal ini jika sering terjadi akan mempengaruhi kualitas SDM untuk menggali potensi pajak/retribusi yang ada di Kabupaten Kepulauan Anambas.

\section{Perumusan Alternatif Strategi Melalui Analisis SWOT}

Alternatif strategi dalam peningkatan PAD di Kabupaten Kepulauan Anambas dapat dirumuskan dengan pendekatan analisis SWOT. Analisis matrik SWOT merupakan langkah selanjutnya setelah dilakukan analisis IFE dan EFE, yakni dengan mencocokkan faktor-faktor internal berupa kekuatan dan kelemahan dengan faktor-faktor eksternal berupa peluang dan ancaman yang berpengaruh dalam peningkatan PAD di Kabupaten Kepulauan Anambas. 
Tabel 4 Matriks SWOT Strategi Peningkatan PAD di Kabupaten Kepulauan Anambas

\begin{tabular}{|c|c|c|}
\hline Faktor Eksternal & $\begin{array}{l}\text { Kekuatan (S) } \\
\text { 1. Kebijakan Pemerintah Daerah } \\
\text { dalam mendukung } \\
\text { pengelolaan pendapatan } \\
\text { daerah } \\
\text { 2. Adanya Perda yang mengatur } \\
\text { tentang penerimaan daerah } \\
\text { 3. Produktivitas organisasi yang } \\
\text { cukup baik } \\
\text { 4. Adanya komitmen Pemerintah } \\
\text { Daerah dalam meningkatkan } \\
\text { PAD } \\
\text { 5. Adanya tupoksi yang jelas } \\
\text { bagi petugas pengelola PAD }\end{array}$ & $\begin{array}{l}\text { Kelemahan (W) } \\
\text { 1. Sumber daya aparatur yang } \\
\text { kurang profesional dan } \\
\text { belum sesuai dengan latar } \\
\text { belakang pendidikan } \\
\text { 2. Sarana dan Prasarana yang } \\
\text { belum memadai } \\
\text { 3. Keterbatasan data potensi } \\
\text { daerah } \\
\text { 4. Target belum sepenuhnya } \\
\text { berdasarkan potensi yang ada } \\
\text { 5. Sistem pengelolaan } \\
\text { keuangan daerah yang belum } \\
\text { maksimal }\end{array}$ \\
\hline $\begin{array}{l}\text { Peluang (O) } \\
\text { 1. Masih ada objek } \\
\text { pajak/retribusi yang belum } \\
\text { tergali } \\
\text { 2. Potensi ekonomi daerah } \\
\text { 3. Adanya keterlibatan dan } \\
\text { kerjasama beberapa } \\
\text { instansi dalam penerimaan } \\
\text { PAD Ilmu } \\
\text { 4. Kemajuan jumlah } \\
\text { pengetahuan dan teknologi } \\
\text { 5. Perkembangan jun } \\
\text { penduduk }\end{array}$ & 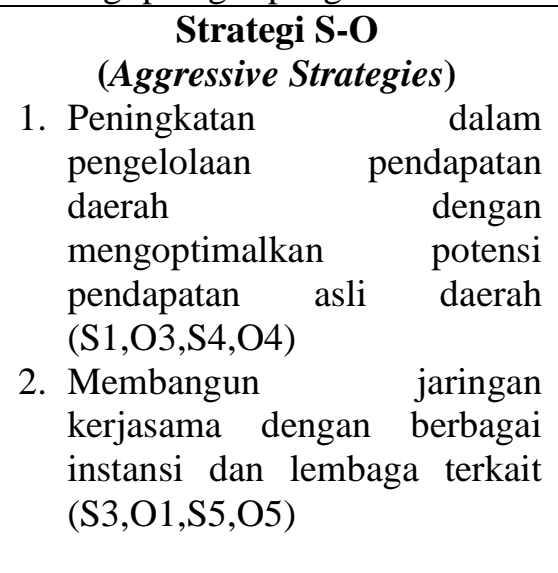 & $\begin{array}{l}\text { Strategi W-O } \\
\text { (Turn Arround Strategies) } \\
\text { 1. Perbaikan sistem informasi } \\
\text { dan pendokumentasian data } \\
\text { wajib pajak daerah } \\
\text { (W3,O2,W4,O3) } \\
\text { 2. Peningkatan sarana dan } \\
\text { prasarana penunjang PAD } \\
\text { (W2,O1,W3,O4) }\end{array}$ \\
\hline $\begin{array}{l}\text { Ancaman (T) } \\
\text { 1. Instabilitas keamanan } \\
\text { 2. Mutasi dan promosi } \\
\text { jabatan terhadap aparatur } \\
\text { pengelola pendapatan } \\
\text { daerah } \\
\text { 3. Tuntutan adanya } \\
\text { pelayanan prima } \\
\text { 4. Perkembangan politik dan } \\
\text { ekonomi } \\
\text { 5. Rendahnya kepatuhan } \\
\text { terhadap peraturan } \\
\text { perundang-undangan }\end{array}$ & 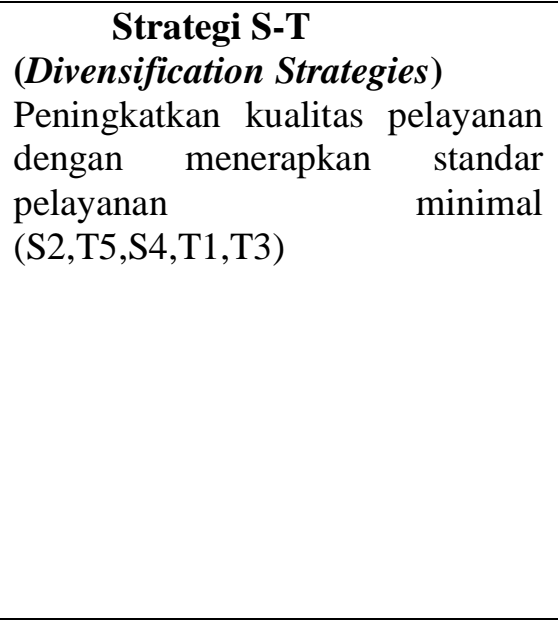 & $\begin{array}{l}\text { Strategi W-T } \\
\text { (Defensive Strategies) } \\
\text { 1. Peningkatan mutu kualitas } \\
\text { SDM pengelola PAD } \\
\text { (W1,T3,W5,T4) } \\
\text { 2. Mengurangi } \\
\text { perpindahan/mutasi aparatur } \\
\text { pengelola PAD dengan } \\
\text { mengalokasikan anggaran } \\
\text { dalam peningkatan kinerja } \\
\text { pengelola } \\
\text { (W1,T2,T3,T4) PAD }\end{array}$ \\
\hline
\end{tabular}

\section{Tahapan Perumusan Strategi Melalui QSPM}

Untuk menentukan prioritas strategi peningkatan penerimaan RSU-HD alat yang digunakan adalah Matriks QSPM. Menurut David (2015) QSPM adalah alat yang memungkinkan ahli strategi untuk mengevaluasi strategi alternatif secara obyektif, berdasarkan pada faktor-faktor kritis untuk sukses internal dan eksternal. Analisis QSPM merupakan lanjutan dari analisis SWOT. Dari rumusan strategi yang didapat dari analisis SWOT kemudian dianalisa dengan cara memberikan nilai daya tarik (Attractive Score/AS) pada masing-masing faktor strategis. 
Tabel 5 Hasil Analisis QSPM Peningkatan PAD di Kabupaten Kepulauan Anambas

\begin{tabular}{|c|c|c|c|}
\hline No & Alternatif Strategi & Skor & Peringkat \\
\hline 1 & $\begin{array}{l}\text { Peningkatan dalam pengelolaan pendapatan daerah dengan } \\
\text { mengoptimalkan potensi Pendapatan Asli Daerah }\end{array}$ & 6.298 & 1 \\
\hline 2 & Peningkatan sarana dan prasarana penunjang PAD & 5.795 & 5 \\
\hline 3 & $\begin{array}{l}\text { Peningkatan kualitas pelayanan dengan menerapkan standar } \\
\text { pelayanan minimal }\end{array}$ & 5.897 & 3 \\
\hline 4 & Peningkatan mutu kualitas SDM pengelola PAD & 6.144 & 2 \\
\hline 5 & $\begin{array}{l}\text { Perbaikan sistem informasi dan pendokumentasian data wajib } \\
\text { pajak daerah }\end{array}$ & 5.766 & 6 \\
\hline 6 & $\begin{array}{l}\text { Membangun jaringan kerjasama dengan berbagai instansi dan } \\
\text { lembaga terkait }\end{array}$ & 5.804 & 4 \\
\hline 7 & $\begin{array}{l}\text { Mengurangi perpindahan/mutasi aparatur pengelola PAD dengan } \\
\text { mengalokasikan anggaran dalam peningkatan kinerja pengelola } \\
\text { PAD }\end{array}$ & 5.428 & 7 \\
\hline
\end{tabular}

Berdasarkan hasil urutan peringkat strategi pada Tabel 4 maka dibuatlah program dan kegiatan dalam rangka peningkatan pendapatan asli daerah di
Kabupaten Kepulauan Anambas, sehingga diharapkan nantinya akan meningkatkan penerimaan daerah dari tahun ke tahun.

\begin{tabular}{ll}
\hline No & Strategi \\
\hline 1 & $\begin{array}{l}\text { Peningkatan dalam } \\
\text { pengelolaan pendapatan } \\
\text { daerah dengan } \\
\text { mengoptimalkan potensi PAD }\end{array}$ \\
& $\quad \begin{array}{l}\text { Peningkatan mutu kualitas } \\
\text { SDM pengelola PAD }\end{array}$ \\
& $\begin{array}{l}\text { Peningkatan kualitas } \\
\text { pelayanan dengan menerapkan } \\
\text { standar pelayanan minimal }\end{array}$ \\
& $\begin{array}{l}\text { Membangun jaringan } \\
\text { kerjasama dengan berbagai } \\
\text { instansi dan lembaga terkait }\end{array}$ \\
& $\quad \begin{array}{l}\text { Peningkatan sarana dan } \\
\text { prasarana penunjang PAD }\end{array}$
\end{tabular}

Perbaikan sistem informasi

6 dan pendokumentasian data wajib pajak daerah

Program

Peningkatan dan

Pengembangan Pengelolaan

Keuangan Daerah

Peningkatan dan

Pengembangan Pengelolaan

Keuangan Daerah

Peningkatan iklim investasi

dan realisasi investasi

Peningkatan dan

Pengembangan Pengelolaan

Keuangan Daerah

Peningkatan iklim investasi dan realisasi investasi

Peningkatan dan Pengembangan Pengelolaan Keuangan Daerah
Kegiatan

a. Intensifikasi dan ekstensifikasi sumbersumber pendapatan daerah

b. Optimalisasi penerimaan pajak daerah

Bimbingan teknis pengelolaan keuangan daerah

Peningkatan kualitas pelayanan perizinan

a. Rekonsialisasi data keuangan triwulan Perangkat Daerah dan instansi vertikal lainnya

b. Rapat koordinasi tentang PAD dengan instansi terkait Penyediaan sarana dan prasarana PTSP

a. Pendataan, perekaman, pemutakhiran, dan analisis ZNT pajak bumi dan bangunan perdesaan dan perkotaan

b. Pemeliharaan sistem informasi pengelolaan keuangan daerah

Meningkatkan koordinasi antar pimpinan SKPD dalam merotasi dan mutasi setiap 23 aparatur pengelola PAD 


\section{KESIMPULAN}

Berdasarkan hasil dan pembahasan yang dilakukan pada kajian mengenai peningkatan pendapatan asli daerah di Kabupaten Kepulauan Anambas, maka diperoleh beberapa kesimpulan sebagai berikut :

1. Berdasarkan analisis Rasio efektivitas PAD Kabupaten Kepulauan Anambas selama periode kajian dapat dikatakan berfluktuatif. Namun dilihat pada Tahun 2014 dan 2015 menunjukkan rasio yang tidak efektif dan kurang efektif. Untuk itu, pemerintah daerah perlu memperbaiki perencanaan dan menggali potensi-potensi PAD, serta melakukan perhitungan target berdasarkan potensi yang sebenarnya. Rasio efisiensi Kabupaten Kepulauan Anambas selama periode kajian Tahun 2011-2015 dapat dikatakan efisien.

2. Kemandirian pemerintah Kabupaten Kepulauan Anambas terhadap pemerintah pusat masih sangat rendah, sehingga dapat dikatakan ketergantungan Pemerintah Daerah Kabupaten Kepulauan Anambas terhadap dana perimbangan masih sangat tinggi.

3. Strategi prioritas yang dapat diimplementasikan untuk meningkatkan PAD di Kabupaten Kepulauan Anambas adalah Peningkatan dalam pengelolaan pendapatan daerah dengan mengoptimalkan potensi Pendapatan Asli Daerah.

\section{DAFTAR PUSTAKA}

Baihaqi. 2011. Analisis Kontribusi Pendapatan Asli Daerah terhadap Pendapatan Daerah Provinsi Bengkulu. Jurnal Akuntansi. 1(3): 246-266.

[BKD]. Badan Keuangan Daerah Kabupaten Kepulauan Anambas. 2016. Laporan Realisasi Pendapatan Kabupaten Kepulauan Anambas
2009-2015. Anambas (ID). Badan Keuangan Daerah.

David FR. 2010. Manajemen Strategis. Buku 1 Edisi 12. Jakarta (ID): Salemba Empat.

David FR. 2015. Strategic Management: Concepts and Cases. 15th Ed. Essex (GB): Pearson Education Limited.

Kaho, JR. 1997. Prospek Otonomi Daerah di Negara Republik Indonesi. Jakarta (ID): PT. Raja Gratondo Persada, Cetakan Keempat.

Mahmudi. 2010. Analisis Laporan Keuangan Pemerintah Daerah. Yogyakarta (ID): UPP STIM YKPN.

Pemerintah Republik Indonesia. 2004. Undang-Undang Nomor 32 Tahun 2004 tentang Pemerintah Daerah. Jakarta (ID). Sekretariat Negara.

Pemerintah Republik Indonesia. 2004. Undang-Undang Nomor 33 Tahun 2004 tentang Perimbangan Keuangan antara Pemerintah Pusat dan Pemerintahan Daerah. Jakarta (ID). Sekretariat Negara.

Pemerintah Republik Indonesia. 2008. Undang-Undang Nomor 33 Tahun 2008 tentang Pembentukan Kabupaten Kepulauan Anambas Provinsi Kepulauan Riau. Jakarta (ID). Sekretariat Negara.

Pemerintah Republik Indonesia, UndangUndang Nomor 23 Tahun 2014 tentang Pemerintahan Daerah. Jakarta (ID). Sekretariat Negara. 